\title{
Efficiency of Insurance Firms with Endogenous Risk Management and Financial Intermediation Activities
}

\author{
J. David Cummins, The Wharton School \\ Georges Dionne*, HEC Montréal \\ Robert Gagné, HEC Montréal \\ Abdelhakim Nouira, HEC Montréal
}

April 28, 2006

\begin{abstract}
Risk management is now present in many economic sectors. This paper investigates the role of risk management in creating value for financial institutions by analyzing U.S. property-liability insurers. Property-liability insurers are financial intermediaries whose primary role in the economy is risk pooling and risk bearing. The risk pooling and risk bearing functions performed by insurers are the primary determinants of the need for risk management. The main goal of this paper is to test how risk management and financial intermediation activities create value for insurers by enhancing economic efficiency. Insurer cost efficiency is measured relative to an econometric cost frontier. Since the prices of risk management and financial intermediation services are not observable, we consider these two activities as intermediate outputs and estimate their shadow prices. The shadow prices isolate the contributions of risk management and financial intermediation to insurer cost efficiency. The econometric results show that both activities significantly increase the efficiency of the property-liability insurance industry.
\end{abstract}

* Corresponding author: Georges Dionne, Canada Research Chair in Risk Management, HEC Montréal, 3000, Chemin de la Côte-Sainte-Catherine, Montreal (Qc) Canada, H3T 2A7. Phone: (514) 340-6596; fax: (514) 340-5019; e-mail: georges.dionne@hec.ca.

The authors thank François St-Cyr for his valuable research assistance and FQRSC and CREF for financial support. 


\section{Efficiency of Insurance Firms with Endogenous Risk Management and Financial Intermediation Activities}

\section{Introduction}

Risk management is now present in many economic sectors. Although perfect markets finance theory provides little rationale for widely held firms to expend resources to hedge unsystematic risk, various market imperfections create opportunities for such firms to maximize market value through hedging. The principal market imperfections that motivate corporate hedging are corporate income taxation (Smith and Stulz, 1985; Graham and Smith, 1999; Graham and Rogers, 2002), financial distress costs (Smith and Stulz, 1985; Dionne and Garand, 2003; Dionne and Triki, 2004), investment opportunity costs (Froot, Scharfstein, and Stein, 1993; Froot and Stein 1998), information asymmetries (DeMarzo and Duffie, 1991), and corporate governance considerations (Dionne and Triki, 2005). Firms also engage in hedging for non-value-maximizing reasons such as managerial risk aversion (Stulz, 1990, Tufano, 1996; Triki, 2005).

For financial firms, matters are more complicated because the customers are also concerned about risk exposure. Banks are heavily regulated because the managers' behavior may affect the risk of the depositors and even the entire financial system (Crouhy, Galai, and Mark, 2000; Dionne, 2004; Morisson and White, 2005). Insurers are also regulated for similar reasons to protect policyholders against insolvency (Cummins, Phillips, and Smith, 2000). Policyholders and depositors cannot diversify their risk by using many insurers or banks because this is costly, and they do not perfectly monitor the managers of these institutions because monitoring is costly and requires specialized expertise. Moreover, the existence

of government deposit insurance and insurance guaranty funds reduce incentives for monitoring and creates moral hazard. This form of moral hazard may explain the risk taking behavior of managers in both industries. Monitoring by customers is also impeded by the opacity of key financial statement items such as bank loans and insurance loss reserves. Risk capital is another form of protection (Merton and Perold 1993). But this is costly and a role for risk management is to reduce risk capital.

The objective of this paper is to provide new information on the role and importance of risk 
management in financial institutions by analyzing a sample of firms from the U.S. property-liability insurance industry. Insurers are financial intermediaries who borrow money from their policyholders in the form of premium payments and invest the funds raised in financial assets. Thus, financial intermediation is one important activity that generates value for insurers. An equally important economic function of property-liability insurers is to provide risk pooling (diversification) and risk bearing services to their policyholders, and these services are a primary driver of the need for risk management. Moreover, both insurer assets generated by the intermediation function and liabilities generated from the risk pooling function are sensitive to inflation and interest rates, creating the need for asset-liability (interest rate risk) management.

The main objective of this paper is to test how risk management and financial intermediation activities create value for insurers by enhancing economic efficiency. We argue that risk management and financial intermediation are two activities that may be used by insurers to improve efficiency, where efficiency is gauged by the capacity to reduce the costs of providing insurance. We measure insurer efficiency by estimating an econometric cost frontier. Because risk management and financial intermediation are key activities for insurers, we treat these activities as endogenous. And, because the prices of risk management and financial intermediation services are not observable, we consider these two activities as intermediate outputs and estimate their shadow prices. The shadow prices are then used to isolate the contributions of risk management and financial intermediation to insurer cost efficiency, as measured by their capacity to reduce costs.

Another contribution of the paper is to develop a theoretical model of value-added in the property-liability insurance industry. This is important because output estimation for financial services firms has been based primarily on the value-added approach in the recent literature. Our model represents a significant extension and generalization of prior models of value-added in the insurance industry by including insolvency risk and explicitly adding risk management as part of value added. The final important contribution of this paper is related to the econometric estimation of the cost frontier. Our econometric methodology, borrowed from the exhaustible resources literature (Halvorsen and Smith, 
1991; Chermak and Patrick, 2001), enables us to estimate the shadow prices of risk management and financial intermediation. By way of preview, our econometric results show that both activities increase significantly the efficiency of the property-liability insurance industry in the United States.

The remainder of the paper is organized as follows. Section 2 reviews the literature on efficiency and performance measures in property-liability insurance. Section 3 analyses outputs of insurers related to risk-pooling, financial management and risk management as components of the insurance industry valueadded. Section 4 proposes the econometric model and estimation method, while Section 5 presents the data and variables. Section 6 analyses the main results and Section 7 concludes.

\section{Literature review}

An extensive literature has developed on the efficiency of financial institutions. A review of the literature a decade ago identified 130 financial institution efficiency studies, and the literature has continued to grow. (Berger and Humphrey, 1997). Cummins and Weiss (2000) review twenty-one insurance efficiency studies over the period 1983-1999, and there have been an approximately equal number of studies since that time.

The state-of-the-art methodology for efficiency estimation is modern frontier efficiency analysis (Fried, Lovell, and Schmidt, 1993). Modern frontier efficiency analysis estimates "best practice” efficient frontiers consisting of the dominant firms in an industry. The efficiency of other firms in the industry is measured relative to the frontiers. Various types of efficient frontiers can be estimated including production, cost, revenue, and profit frontiers. Two principal methodologies have been used to estimate frontiers: (1) Stochastic frontier estimation using parametric econometric models and (2) non-parametric estimation methods such as data envelopment analysis (DEA). Both methods have advantages and disadvantages, but comparative analyses have shown that they tend to give consistent results when applied to the same dataset, in terms of ranking firms by their relative efficiency (Cummins and Zi, 1998; Casu, Girardone, and Molyneux, 2004). We adopt the econometric approach in this paper because it facilitates the estimation of shadow prices for financial and risk management.

Most of the existing insurance efficiency studies utilize the estimated efficiencies to test various 
economic hypotheses. Insurance efficiency studies have been conducted to test for economies of scale (Cummins and Santomero, 1999; Cummins and Xie, 2005), economies of scope (Berger, et al. 2000), and the relative efficiency of product distribution systems (Berger, Cummins, and Weiss, 1997; Klumpes, 2004). Other studies have considered deregulation and consolidation (Cummins and Weiss, 2000b; Mahlberg and Url, 2003; Cummins and Rubio-Misas, 2006; Hussels and Ward, 2006), capital utilization (Cummins and Nini, 2002), and organizational form (Cummins and Zi, 1998; Cummins, Weiss, and Zi, 1999; Cummins, Rubio-Misas, and Zi, 2004; Greene and Segal, 2004). The relationship between market structure and performance has been investigated by Ennsfellner, Lewis, and Anderson (2004), Choi and Weiss (2005), and Fenn, et al., (2006). There have been approximately an equal number of studies on the life and property-casualty (non-life) insurance industries.

Perhaps surprisingly, none of the existing insurance efficiency studies considers risk management as a potential determinant of firm performance, although some studies have considered the importance of solvency risk and overall capitalization (leverage) (e.g., Cummins and Nini, 2002). Several papers have analyzed insurer risk management using other methodologies. Staking and Babbel (1995) analyze the relationship between capital structure, interest rate risk, and market value for U.S. property-liability insurers. The results indicate a non-linear relationship between firm value and interest rate risk and support the hypothesis that insurers manage interest rate risk to protect their franchise values. Cummins, Phillips, and Smith (2001) analyze the determinants of the use of derivatives by insurers and find evidence consistent with the hypothesis that insurers are using derivatives to manage risk. However, they do not test the relationship between derivatives usage and insurer financial performance. Thus, an important contribution of the present study in comparison with the previous literature is the explicit consideration of risk management as a determinant of firm performance using cost structure analysis. Likewise, although most of the prior literature treats insurers as financial intermediaries, none of the prior studies has attempted to estimate the shadow price of the financial intermediation function.

The lack of prior research in this area is partially due to data limitations - the detailed data needed to measure risk management activities with any precision are not yet available to researchers studying 
European or Asian insurance companies. Although more detailed data are available on U.S. insurers, some of this information was not available electronically until very recently. We take advantage of the more detailed U.S. data, including the recently released electronic databases on certain types of insurer risk management activities, to measure the effects of risk management on firm performance. Our database is described in more detail below.

Although there have been no studies of the insurance industry that explicitly consider the relationship between risk management and firm efficiency, there have been a few studies on banking and non-financial industries that attempt to make the connection between risk management and performance. However, few of these studies have examined risk management in the context of frontier efficiency analysis. For example, Brewer, Jackson, and Moser (1996) analyze the use of derivatives by U.S. savings and loan associations (S\&Ls) and find evidence that S\&Ls use derivatives to manage risk - equity return volatility is inversely related to the level of derivatives activity and derivative users pay a lower rate on large certificates of deposit than non-users. Schrand and Unal (1998), in a study of demutualizing savings and loans, show that converting thrift institutions use hedging to reduce exposure to risks that provide zero economic rents (such as interest rate risk) and to increase exposure to risks that provide positive rents (such as credit risk). Drzik (2005) provides evidence that bank investment in risk management during the 1990s helped reduce earnings and loss volatility during the 2001 recession. Cebenoyan and Strahan (2004) find evidence that banks engaging in active management of credit risk exposure through the loan sales market have lower risk and higher profits than other banks.

Several studies have analyzed the risk management-performance relationship for non-financial firms. For example, Allayannis and Weston (2001) analyze the use of foreign currency derivatives (FCDs) by nonfinancials and find a positive relationship between firm value and the use of FCDs. Nelson, Moffitt, and Affleck-Graves (2005) find that nonfinancial firms that hedge using derivatives outperform non-hedgers but that the effect is primarily due to the use of FCDs by relatively large firms. Finally, Jin and Jorion (2006) find that risk management has no effect on oil industry firms' market value, and Dionne and Triki (2006) verify that risk management in the gold mining industry increases returns on assets. 
Another important strand of the banking literature emphasizes the importance of including nontraditional outputs such as off-balance sheet (OBS) activities as well as controls for risk in estimating bank efficiency (e.g., Mester, 1996; Stiroh, 2000; Hughes, et al., 2001; Clark and Siems, 2002; Girardone, Molyneux, and Gardener, 2004; Casu and Girardone, 2005; Pastor and Serrano, 2005). These studies show that failing to account for non-traditional outputs and for risk can lead to misleading efficiency estimates and thus reinforce the argument for controlling for such factors in the present study. However, this set of papers generally does not focus on the relationship between risk management and efficiency.

\section{Insurer value-added}

We treat risk management as an answer to policyholders' demand for reducing solvency risk related to insurance contracts. We do not consider other determinants of risk management such as taxes, financial distress costs, investment financing or managers' risk aversion (Cummins, Phillips, and Smith, 2000). In other words, in our model only the clients’ risk aversion explains risk management. Without any insolvency problems, the risk premium a representative insured is willing to pay over the actuarial value of the contract is given by the solution to the following equation:

$$
\int_{0}^{\bar{L}} U\left(W_{0}-L\right) f(L) d L=U\left(W_{0}-E(L)-\pi_{R}\right),
$$

where $W_{0}$ is initial wealth of the insurance buyer, $L$ measures a given loss for the insured, $f(L)$ is its corresponding density, and $\bar{L}$ is the maximum possible value of loss. The left hand side is the noinsurance situation and the right hand side corresponds to the insurance situation, assuming there is full insurance coverage, that is $q(L)=L$ for all $L$ where $q(L)$ is the insurance coverage of loss $L . \pi_{R}$ is the Arrow-Pratt risk premium for risk-pooling or the maximal amount a risk averse insured is willing to pay above the actuarial value of the contract, i.e., the expected loss $E(L)$. So the maximal premium for riskpooling is equal to $E(L)+\pi_{R}$. A private monopoly will extract the entire surplus $\pi_{R}$. Under competition, however, the monopoly rent will be nil and the insurance surplus will be split between the policyholders and the insurer. 
If we introduce the possibility of insurer insolvency to the insurance contracting problem (Doherty and Schlesinger, 1990; Doherty and Dionne, 1993) and continue to assume, for a moment, that the insured still buy full coverage for the insurable loss when he is compensated by the insurer and receives no coverage when a solvency problem occurs, the corresponding total risk premium solves the following equation:

$$
p \int_{0}^{\bar{L}} U\left(W_{0}-L-P_{S}\right) f(L) d L+(1-p) U\left(W_{0}-P_{S}\right)=U\left(W_{0}-P_{S}-\pi_{S}\right)
$$

where

$P_{S} \quad$ is the actuarial insurance premium for the risk-pooling activity in presence of solvency risk;

$p \quad$ is the probability of the non-solvency state;

$\pi_{S}$ is the total risk premium for both solvency risk and risk pooling.

Consequently, the insured is willing to pay $\pi_{S}$ above $P_{S}$ to get full insurance and full security against solvency risk. It can be shown that $\pi_{S}>\pi_{R}$ under regularity conditions. We implicitly assume here that the insured buys full insurance for the insurable risk, which is a possible solution (Doherty and Schlesinger, 1990). This assumption is not necessary to get $\pi_{S}>\pi_{R}$.

There are different types of output measures in the insurance literature (Cummins and Weiss, 2000). In this study, we use the value-added approach (Berger and Humphrey, 1992), which is the most widely accepted approach in the financial institutions literature. Under this approach, the output measure has four components: a) risk-pooling or direct insurance coverage; b) risk-bearing or risk management; c) financial management, and d) financial services related to insured losses (Cummins and Weiss, 2000). In this paper, we emphasize the first three components; but our output measures (discussed below) also provide excellent proxies for the fourth.

If we limit the discussion, for the moment, to the risk-pooling component without solvency risk and intermediation, we can measure the corresponding value-added by the difference between the 
insurance premium and the insurance output. As shown in (1), risk averse insureds are willing to pay $\pi_{R}$ over the expected losses to get insurance coverage.

We can write the competitive insurance premium $\left(P_{P}\right)$ as:

$$
P_{P}=\frac{Q\left(1+e_{q}\right)+r_{e} E}{1+r_{0}}
$$

where:

$Q$ is the expected insurance compensation, under full insurance above a deductible; $Q=\left.(E(L)-D)\right|_{L>D}$, where $D$ is a deductible;

$e_{q}$ is the insurer expenses as a proportion of expected compensation;

$E \quad$ is total equity;

$r_{e}$ is the return required by equity holders to invest in the insurance industry;

$r_{0}$ is the risk-free interest rate required by policyholders.

So, the corresponding value-added can be written as:

$$
V_{p}=P_{P}+\left(P_{P}+E\right) r_{0}-Q-r_{e} E
$$

or, equivalently, as:

$$
V_{P}=e_{q} Q+r_{0} E
$$

which corresponds to the fraction of the risk premium available to the insurance industry under competition. It is equal to the insurer expenses for direct insurance plus the investment return on equity. Insurers can improve this added value by offering more insurance at a lower cost.

The corresponding price of insurance for risk-pooling is then equal to:

$$
\text { Price }=\frac{P_{P}-Q / 1+r_{0}}{Q / 1+r_{0}}=e_{q}+\frac{E}{Q} r_{0} \text {. }
$$

This price is observable or measurable. We may add the intermediation component by defining 
$\left(1+r_{a}\right)=\left(1+r_{p}\right)(1+m)$ where $m$ is the net interest margin received by the insurer for performing the intermediation function, $r_{p}$ is the required interest rate by policyholders under market risk $\left(r_{p}>r_{0}\right)$, and $r_{a}$ is the investment return obtained from the financial intermediation function. We still assume here that there is no solvency risk and, to simplify the notation, the financial intermediation expenses are included in $e_{q} Q$. The corresponding total value-added for risk pooling and financial intermediation can be written as (Cummins and Weiss, 2000):

$$
V_{P F}=m\left(Q\left(1+e_{q}\right)+r_{e} E\right)+\left(e_{q} Q+r_{a} E\right)
$$

The intermediation function creates additional added value via two effects: $r_{a}>r_{0}$ and when $m>0$ or when the required return by policyholders $r_{p}$ is smaller than the investment return $r_{a}$.

One contribution of this paper is to add explicitly the risk-bearing or risk management component to this definition. If we now assume that the policyholders value the security offered by insurers that hold capital to cushion unexpected losses and investment shocks due to random interest rates, for example, this means that the value-added of insurance should contain an extra source. We can introduce this extra source by supposing that the expected compensation is random without risk management activities by the insurer. For example, the expected compensation can be written as $(1-p) Q$, where $p$ is the probability of the non-solvency state, which implies that the expected loss due to insolvency is $p Q$. For a risk averse insured, this supplementary random variable represents an additional risk with respect to his loss net of insurance coverage and, as shown above, he is willing to pay a total premium $P_{S}+\pi_{S}$ to reduce or eliminate this additional risk along with the insurable risk. For simplicity, we define $h$ as the hedging ratio of the additional risk $(0 \leq h \leq 1)$. When $h=1$, the insurer has eliminated the extra risk and when $h=0$, the insurer does not hedge at all this additional risk. We suppose that $h$ is observable in the market and that $e_{h}$ is the additional proportional cost related to risk management.

Consequently (3) becomes: 


$$
P_{P F M}=\frac{\left(Q+r_{e} E\right)(1-p+p h)+e_{h q} Q}{\left(1+r_{h}\right)},
$$

where $e_{h q}$ is insurer expenses including the risk-management activity $\left(e_{h q}=e_{q}+h e_{h}\right)$ and $r_{h}$ is the required interest rate by policyholders under market and solvency risk. We implicitly assume that it is optimal for the equity holders to manage this additional risk on security markets (so $r_{e}$ is not modified). Insurer expenses are not subject to solvency risk, i.e., the solvency risk occurs at the end of the contracting period after all expenses $\left(e_{h q} Q\right)$ have been paid. However, both the equity holders' income and the policyholders' loss recoveries are subject to the solvency risk. When $h=1, r_{h}=r_{p}$ (only the market risk remains) and when $h<1, r_{h}>r_{p}$. Solvency risk also affects the value of the net interest margin received by the insurer for performing the intermediation function, when $r_{h}>r_{p}$. So $\left(1+r_{a}\right)=\left(1+r_{h}\right)\left(1+m_{r}\right)$, where $r_{a}$ is the investment return and $m_{r}$ is the net interest margin under market and solvency risk.

The total value-added then becomes equal to:

$$
V_{P F M}=m_{r}\left(e_{h q} Q+(1-p+p h)\left(Q+r_{e} E\right)\right)+\left(e_{q} Q+r_{a} E\right)+e_{h} h Q-c(h)
$$

which is the value added from intermediation, plus the value added from risk-pooling, plus the value added from risk management. $c(h)$ measures cash outflows that can be paid for some risk management activities such as reinsurance or consultant services. In the Appendix, we derive explicitly equation (7).

For property-liability insurers, it is usually possible to measure the risk-pooling insurance output and its corresponding price, as given in (4). Matters are much more complicated for the financial intermediation and risk management activities. To solve this problem, we propose to treat these two activities as intermediate outputs that have separable quantities of inputs from those used in the riskpooling activity. So we will be able to estimate the shadow prices of both the financial intermediation and the risk management activities. The financial intermediation intermediate output will be measured by the invested assets, while the risk management intermediate output will be associated to the dollar duration of 
surplus (insurer equity capital) defined as the difference between the dollar duration of assets and the dollar duration of liabilities. By dollar duration we mean duration in years times monetary value. High risk management output will correspond to small dollar duration surplus. We know this is limited to a first-order approximation but it corresponds to a good proxy of risk management.

With the above formulation of risk management, its benefits are not limited to the increase in firm value but are also transferred to the policyholders. One interesting result will be to test whether the presence of risk management improves the efficiency of insurance-pooling and reduces its costs.

\section{Econometric Model and Estimation Method}

We assume that insurance services $(Q)$ are produced using a vector of inputs $\left(X^{A}\right)$ and two intermediate outputs - financial intermediation and risk management - according to the following production function:

$$
Y\left(Q ; R, F, X^{A}, Z, T\right)=0,
$$

where $Z$ is a vector of control variables which may contain quasi-fixed inputs, and $T$ represents time (for simplicity, we omit the time and firm subscripts). $R$ and $F$ are the intermediate outputs representing risk management and financial intermediation activities.

The technology associated with the production of risk management is defined as:

$$
R=R\left(X^{R}, Z, T\right)
$$

where $X^{R}$ are inputs used in the production of risk management. Similarly, the technology associated with financial intermediation:

$$
F=F\left(X^{F}, Z, T\right),
$$

where $X^{F}$ are inputs used in the production of financial intermediation.

Under the assumption that insurance firms are cost minimizers, and that $Q, R$, and $F$ are predetermined, the restricted cost function associated with the technology described by (8), (9) and (10) is:

$$
C R=C R\left(Q, R, F, P^{A}, P^{R}, P^{F}, Z, T\right),
$$


where $C R$ are total costs, and $P^{A}, P^{R}$, and $P^{F}$ are, respectively, the prices of inputs $X^{A}, X^{R}$ and $X^{F}$. The restricted cost function defined by (11) gives the minimum cost of producing the level of insurance services $Q$, given the levels of risk management and financial intermediation undertaken by the firm ( $R$ and $F$ ), the different input prices $\left(P^{A}, P^{R}\right.$, and $P^{F}$ ), the state of the control variables $(Z)$, and time $(T)$, which is included to take into account technical change.

Following Halvorsen and Smith (1991), we obtain the implicit (or shadow) prices of risk management $(\mu)$ and financial intermediation $(\lambda)$ using the partial derivatives of the restricted cost function with respect to $R$ and $F$ :

$$
\mu=-\frac{\partial C R}{\partial R}
$$

and

$$
\lambda=-\frac{\partial C R}{\partial F}
$$

Since the exact functional form of the restricted cost function defined by (11) is unknown, we use the well known translog approximation which is given by:

$$
\begin{aligned}
\ln C R_{i t} & =\alpha_{i}+\sum_{v} \beta_{v}^{Q} \ln Q_{v i t}+\beta_{i}^{R} \ln R_{i t}+\beta_{i}^{F} \ln F_{i t} \\
& +\sum_{s} \beta_{s}^{A} \ln P_{s i t}^{A}+\sum_{j} \beta_{j}^{R} \ln P_{j i t}^{R}+\sum_{k} \beta_{k}^{F} \ln P_{k i t}^{F} \\
& +\beta^{Z} \ln Z_{i t}+\text { second - order terms }+\sum_{t} \beta^{t} D_{t}+u_{i t},
\end{aligned}
$$

where subscripts $i$ and $t$, represent, respectively, firms and time, and $D_{t}$ are time dummy variables (the sample first year being the omitted category). The coefficients associated with the time dummy variables can be used to compute industry-level technical change. The intercept $\left(\alpha_{i}\right)$ and the coefficients associated with the risk management and financial intermediation variables ( $\beta_{i}^{R}$ and $\beta_{i}^{F}$ ) are firmspecific, allowing, among other things, for firm-specific estimates of the risk management and financial intermediation shadow prices. $\alpha_{i}$ will also be used for the analysis of insurance-pooling efficiency. For 
the estimation, we treat these three parameters as random variables which follow a normal distribution with means $\alpha, \beta^{R}, \beta^{F}$ and variance-covariance $\Omega$. Finally, $u_{i t}$ are i.i.d. random disturbances.

Linear homogeneity of degree one in input prices is imposed prior to estimation by dividing total costs and all input prices but one by this last price. Finally, all continuous variables on the right-hand side of (14) are divided by their sample mean (the point of approximation).

The risk management $(R)$ and financial intermediation $(F)$ variables are likely to be endogenous. The set of instruments used includes the log of the output and input prices, the time dummy variables and other dummy variables measuring insurer's characteristics such as the ownership structure, group membership, and credit quality. ${ }^{1}$ The predicted values of each endogenous variable are obtained from an OLS regression on the set of instruments and are substituted to the actual values in equation (14). Equation (14) is then estimated by restricted/residual maximum likelihood (REML) as it is implemented in the Mixed Model procedure of SAS. The proper test statistics of the different estimated parameters of the model are obtained by running 5,000 simulations. ${ }^{2}$

Shadow prices for risk management and financial intermediation intermediate inputs are computed from (14) using the following equations:

$$
\mu_{i t}=-\frac{\partial \ln C R}{\partial \ln R_{i t}} \frac{C R_{i t}}{R_{i t}}
$$

and

$$
\lambda_{i t}=-\frac{\partial \ln C R}{\partial \ln F_{i t}} \frac{C R_{i t}}{F_{i t}} .
$$

It is possible to compute the shadow prices for each observation in the sample only because they are functions of variables specific to each observation. However, recall that the translog approximation of

\footnotetext{
${ }^{1}$ See Section 5 (Data and Variables) for an exact description of the variables used.

${ }^{2} 5,000$ samples are generated using the estimated distributions of $u_{i t}, \alpha_{i}, \beta_{i}^{R}, \beta_{i}^{F}, R$ and $F$ obtained by maximum likelihood (ML). Then, for each generated sample, equation (14) is estimated again by ML. At the end, proper test statistics for each estimated parameter of the model are computed from these 5,000 estimates.
} 
the restricted cost function includes firm-specific coefficients associated with the risk management and financial intermediation variables. Their estimated values are used to compute $\partial \ln C R / \partial \ln R_{i t}$ and $\partial \ln C R / \partial \ln F_{i t}$. A higher shadow price for a specific insurer (compared to other insurers) indicates the potential cost reductions that could be realised by increasing risk management or financial intermediation activities. A shadow price near zero indicates that an insurer has already internalized the benefits of risk management and financial intermediation into its cost structure. A negative shadow price would be an indication of an over production of risk management or financial intermediation activities.

Finally, the relative residual efficiency of each firm in the sample can be computed using the stochastic part of the cost function. This is the efficiency that cannot be attributable to any specific input or intermediate output. Two efficiency measures are used. The first one is analogous to the measure proposed by Berger (1993):

$$
\operatorname{Efficiency}(1)_{i}=\exp \left(\alpha_{\min }-\alpha_{i}\right)
$$

It defines relative efficiency as the ratio of the minimum cost needed (costs of the fully efficient firm) to the actual costs expanded. To measure the relative efficiency of insurance firm $i$, we also consider relative inefficiency defined as the ratio of the actual costs expanded to the maximum cost needed (costs of the fully inefficient firm). Under the alternative definition efficiency is given by:

$$
\operatorname{Efficiency}(2)_{i}=1-\exp \left(\alpha_{i}-\alpha_{\max }\right)
$$

\section{Data and Variables}

\subsection{Data}

The primary database for our project consists of the regulatory annual statements filed by U.S. property-liability insurers with the National Association of Insurance Commissioners (NAIC). We use data for all property-liability insurance firms that report to the NAIC for the period 1995 through 2003. However, we eliminate reporting firms showing negative surplus, assets, losses or expenses. Such firms are not viable operating entities but are retained in the database by the NAIC for regulatory purposes such as the resolution of insolvencies. Because insurers formulate investment and risk management strategies 
at the overall corporate level, our analysis focuses on groups of insurers under common ownership and unaffiliated single insurance firms. Data for insurance groups are obtained by aggregating the data for affiliated insurance firms which are members of the group. The resulting sample consists of 9,854 observations for the 9-year period.

Our analysis is limited to multiple line insurance firms reporting strictly positive output in each of the four lines of insurance business: long-tail personal, short-tail personal, long-tail commercial and shorttail commercial, where the length of the tail refers to the length of the claims payout period for the line of business. ${ }^{3}$ However, for robustness and industry representation results, we also consider a larger sample of firms obtained from the aggregation of the four outputs into only one. In that case, only insurance firms with non-strictly positive total output were deleted. Also, insurers reporting negative input prices or surplus duration have been deleted. Our final samples consist of 9,129 observations for 9 years when we use a single total output, and 3,303 when we use outputs from four lines.

Although the restriction of the smaller sample to insurers with strictly positive outputs in all four lines reduces the sample size, most of the firms eliminated are small specialist firms. In fact, the sample of firms with strictly positive output in all lines accounts for about 84 percent of total industry premium volume in 2003, and the larger sample based on the single output accounts for about 93 percent of total premiums. Thus, because the use of four outputs is likely to give more reliable results and because most of the firms eliminated by the strictly positive output criterion are small specialists, our preferred results are based on the smaller sample of firms active in all four major output categories.

\subsection{Variables}

\subsubsection{Intermediate Outputs}

The quantity of output associated with financial intermediation activities is invested assets (Invested Assets). The dollar duration of the surplus (Asset-liability Risk) is used as a proxy of the quantity of output associated with risk management activities. ${ }^{4}$ The dollar duration of the surplus is defined as: $S D_{S}$

\footnotetext{
${ }^{3}$ Our classification of lines as long-tail and short-tail is based on Schedule P of the NAIC annual statement.

${ }^{4}$ Surplus is the term used for the book-value of equity capital in the insurance industry.
} 
$=A D_{A}-L D_{L}$, where $D_{S}$ is the duration of surplus, $D_{A}$ is the duration of assets, $D_{L}$ is the effective duration of liabilities, $A$ is the market value of invested assets, $L$ is the liability (losses and loss adjustment expenses reserves). The surplus of the firm is immunized $\left(D_{S}=0\right)$ when the effect of the interest rate changes on assets is equal to the effect of interest rate changes on liabilities. We are not assuming that nil duration of surplus is optimal for insurers and we take the dollar duration of the surplus as a measure of the quantity of risk that is left by the risk management activities. We assume that more insurers' risk management activities imply a smaller dollar surplus duration which contributes to increase the insurer's value added for the policyholders.

When the security's cash flows are independent of the interest rate movements, as is the case for bonds, we calculate the Macaulay duration. When the security's cash flows can change with interest rate movements, as is the case with insurance liabilities, we calculate the effective duration. To estimate the effective duration of a cash flow, Ahlgrim, D’Arcy and Gorvett (2004) calculate the present value of the expected cash flow in three ways. The first present value $P V_{o}$ is based on the original term structure. The second present value $P V_{u p}$ is based on a new term structure that is generated if the observed interest rates are increased by a specific amount $(\Delta r)$. The third present value $P V_{\text {down }}$ is based on another term structure that is generated if observed interest rates are decreased by the same specific amount $(\Delta r)$. The effective duration $E D$ is then obtained as: $E D=\frac{P V_{\text {down }}-P V_{u p}}{2 P V_{o} \Delta r}$. We use data from schedule $\mathrm{D}$ of the National Association of Insurance Commissioners (NAIC) insurance regulatory statement to compute the duration of each security owned by the insurance firm as of December 31. For each bond, we estimate the implied yield to maturity from the reported statement value and then we calculate the duration. We consider preferred stocks as perpetual bonds to calculate their duration. We assume that the duration of common stocks is equal to the duration of S\&P 500 (Staking and Babel, 1995). The duration of the S\&P 500 is computed as the duration of perpetual bonds. Finally, we measure the duration of invested assets as the value weighted duration of all securities, including cash with nil duration.

To calculate the effective duration of liabilities, we proceed in four steps. In the first step we use 
the cumulative paid losses and allocated expenses from schedule $\mathrm{P}$ part 3 of the NAIC insurance regulatory statement to estimate the cash flows patterns. ${ }^{5}$ In the second step, we estimate the real value of the future payments. ${ }^{6}$ The third step consists in an inflation adjustment of the future payments to take account of the fact that insurers hold reserves in nominal value. ${ }^{7}$ In the last step, we discount the future payments and we calculate the effective duration. ${ }^{8}$

${ }^{5}$ We deflate the paid losses each year to the real 1995 values based on the consumer price index (CPI). We adopt the chain ladder method to estimate the percentage of ultimate losses that is paid in each development year (Taylor 2000). Because the payout pattern differ between the principal types of insurance's business, we estimate a different chain ladder parameter for personal lines long-tail losses, personal lines short-tail losses, commercial lines long-tail losses and for commercial lines short-tail losses. In each year, we estimate the same chain ladder parameters for the whole property-liability insurance industry.

${ }^{6}$ We determine the real values of incurred losses by accident year as the sum of the real values of unpaid losses and the real value of paid losses. Then we applied the chain ladder parameters found in the first step to calculate the real value of losses that will be paid in the future development years.

${ }^{7}$ We assume that inflation and risk free interest rates are linearly correlated. Thus, the future movement of interest rates will affect the future claim payouts. We use the U.S. Treasury yield curves obtained from the Federal Reserve Economic Database (FRED) as the risk free interest rate term structure. We use Hull and White (1990) term structure model to simulate 1000 paths of interest rates movement. We utilize inflation paths to calculate the inflation adjusted value of future losses. The chain ladder method allows us to determine the loss cash flow patterns for ten years. If the sum of all the inflation adjusted future payments is less than the real value of unpaid losses, we assume that the rest will be paid during the eleventh year.

${ }^{8}$ To determine the effective duration in a last step we need to calculate the present value of future payments in three ways as in Ahlgrim, D’Arcy and Gorvett (2004). The interest rate term structures by insurer's credit quality are obtained from Bloomberg. Actually, these term structures are available only since May 2000 for three different credit qualities AA, A and BBB. The insurer credit rating is obtained from Best’s Key Rating Guide (A.M. Best Co). We use the table of correspondence between A.M Best rating scale and Bloomberg rating scale to split insurers in three different pools. Each pool has a different term structure. We estimate then the average spread between each interest rate term structure and the risk free interest rates term structure during the period 2000-2005 where data are 


\subsubsection{Output Quantities and Output Prices}

Output quantities are calculated every year for each business line: Long-tail personal, Short-tail personal, Long-tail commercial and Short-tail commercial. We also use a measure of aggregated output (Total Output) which is the sum of the four outputs. For a subset of data with the aggregated output, we add two qualitative variables to account for the insurer's output characteristics. The first qualitative variable is the output of personal lines as a proportion of total output (Proportion of personal). The second qualitative variable is the proportion of long-tail lines in total output (Proportion of long-tail). The output quantity for a given year $t$ is defined as the present value of incurred losses arising only from the exposure related to the premiums written during the year $t$. Losses paid during the year $t$ but arising from exposures related to the premiums written during previous years are not included in the year's $t$ output quantity. To calculate the present value of incurred losses we use the chain ladder parameters and the interest rates term structure obtained for the estimation of liabilities' effective duration. ${ }^{9}$

Output prices are calculated as the difference between premiums earned and the output quantity, expressed as a ratio to the output quantity: Output price ${ }_{\mathrm{ikt}}=\left[\right.$ Premium $\left._{\mathrm{ikt}}-Q_{\mathrm{ikt}}\right] / Q_{\mathrm{ikt}}$, where Premium is premium earned, $Q$ is the output quantity, and subscripts $i, k$, and $t$ refer to insurer $i$, output $k$ and year $t$, respectively. Thus for each insurer we obtain four different prices: Price of long-tail personal, Price of short-tail personal, Price of long-tail commercial and Price of short-tail commercial. The Price of total output is computed similarly.

available. We applied these average spreads for the missing period 1995-2000 to find out an equivalent interest term structure for each credit quality.

${ }^{9}$ Alternatively, we also estimated our models with the output quantities defined as the total incurred losses during the year plus the loss reserve adjustment, which includes in year t's output the year t adjustment in reserves for prior years. The inclusion of the reserve adjustment has been used in most of the prior literature (see Cummins and Weiss. 2000a). Because reserve adjustments are usually positive, this alternative measure of output quantities is slightly larger. However, the estimates of shadow prices and efficiencies remain qualitatively the same. These additional estimates are available upon request. 


\subsubsection{Inputs}

Insurance firms use six different inputs: administrative labour services, agent labour services, risk management labour services, materials and business services, debt capital, and equity capital Administrative labour and material/business services are used for the insurance, risk management, and financial intermediation activities of the insurance firms and, therefore, prices are the same. Agent labour services are only used for insurance activities. Risk management labour services are utilized only for the risk management activities. Debt capital and equity capital are inputs used only for financial management.

The price of administrative labour services (Administrative Labour) is the average weekly wage in the U.S. state where the head office of the firm is located for SIC code 6331- Fire, Marine, and Casualty Insurers. The price of agent labour services (Agent Labour) is a weighted average of the average weekly wages in each State where the firm operates for SIC code 6411- Insurance agents and brokers. In that case, the weight is the share of premiums written in each state by the insurance firm. The price of risk management input (Risk Labour) is the average weekly wage in each State where the head office of the firm is located for the North American Industry Classification System (NAICS) code 52392- Portfolio management. The price of material/business services (Business Labour) is the average weekly wage also in the State where the head office is located for SIC code 7300 - Business services. The SIC and NAICS average weekly wages used to compute prices are coming from the U.S. Bureau of Labor Statistics.

The price associated with debt capital (Debt Price) is defined as the required return by policyholders. This required return is a function of the credit quality of the insurer and the expected waiting time between accident occurrence and claim payment. We compute Debt Price for each insurance firm as the annualized interest rate equivalent to the rate on the term structure corresponding to the firm's credit quality and with maturity equal to the effective duration of the insurer's liabilities. This produces a different price for each insurance firm varying by its credit quality and its liability's effective duration. ${ }^{10}$

The price associated with equity capital (Equity Price) is defined as the required return by equity

\footnotetext{
${ }^{10}$ The credit quality term structures are obtained from Bloomberg, and the insurer's credit quality is obtained from Best’s Key Rating Guide (A.M. Best Co).
} 
holders. We use the Fama-French three-factor model to estimate the required returns for listed insurance firms on financial market. ${ }^{11}$ We assume that listed and unlisted insurers that have the same credit quality also have the same required return on equity. In other words, we categorize insurers by debt quality and take an average within each debt rating of the Fama-French cost of capital.

Total costs (Costs) are computed as the sum of total expenses (net of loss adjustment expenses) and the cost of capital. The cost of capital is the sum of the cost of equity capital and the cost of debt capital. ${ }^{12}$ The equity capital (Equity) is defined as the sum of policyholders' surplus and the redundant statutory liabilities (excess of statutory over statement reserve, unauthorized reinsurance plus the unearned premium reserve). The debt capital (Debt) is defined as the sum of loss reserves plus the unearned premium reserve.

\subsubsection{Other Variables}

Yearly dummy variables (Year96-Year03) are used to take into account of time. Also, a set of other dummy variables is used to account for insurer's characteristics. Stock ownership dummy is equal to 1 for stock insurer and equal to 0 otherwise. Group dummy is equal to 1 if the insurer is member of a group of insurers and equal to 0 otherwise. We define six dummy variables to account the insurer credit quality. Class 1 dummy is equal to 1 if insurer's rating is $\mathrm{A}++$ or $\mathrm{A}+$. Class 2 dummy is equal to 1 if insurer's rating is A. Class 3 dummy is equal to 1 if insurer's rating is A -. Class 4 dummy is equal to 1 if insurer's rating is $\mathrm{B}++$ or $\mathrm{B}+$. Class 5 dummy is equal to 1 if insurer's rating is B. Class 6 dummy is equal to 1 if insurer's rating is B -.

\footnotetext{
${ }^{11}$ We split listed insurers into three groups based on their A.M. Best's rating. In every year, we estimate the cost of equity capital for each group. The prices of the Fama-French three risk factors were obtained from Kenneth French's website.

${ }^{12}$ The cost of equity capital is the average quantity of equity capital hold by the insurer during the year multiplied by Equity price. The cost of debt capital is the average quantity of debt capital hold by the insurer during the year multiplied by Debt price.
} 


\subsection{Summary Statistics}

Summary statistics for the variables are presented in Table 1 for two different samples of insurers. The first sample, called Sample 1, represents larger insurers that produce positive output in each of the four lines: Long- and Short-tail personal and Long- and Short-tail commercial. 612 US insurers representing 3,303 observations are contained in this sample. Firms in this sample account for xyz percent of total property-liability premiums written in 2003. When we look at size variables such as Equity, Debt and Assets we observe that these insurers are about twice the size of the those in the total available population composed of 1,636 insurers and 9,129 observations (Sample 2). A third sample of insurers also is analyzed as a robustness check. This sample represents 1,013 insurers totalizing 5,549 observations.

\section{Empirical Results}

Table 2 presents the estimation results of two models. Model 1 is the one which is closer to the literature reference model used to compute cost efficiency (Berger, 1993; Berger, Cummins and Weiss, 1997, and their references). In this model, the coefficients associated with the intermediate outputs are fixed. Model 2 corresponds to the translog model of Equation (14) with random coefficients associated with the two intermediate outputs. Estimation results are similar to Model 1 with two exceptions. Indeed, we observe that the coefficients of the two intermediate outputs are much higher in absolute values in Model 2, although they have the same signs and statistical significance. A negative coefficient for Invested assets means that the financial intermediation activity decreases the insurance activity costs. This result is in line with the theoretical model (Equation 5) where it is shown that financial management may create additional value added when some conditions are satisfied. A positive coefficient for Asset-liability risk is also in line with the theoretical model (Equation 7) where it is shown that risk management may have a positive value on the insurer's value added since it reduces the solvency risk. A positive coefficient means that high risk insurers (those with less risk management activities) have higher insurance costs.

Table 3 presents results with larger samples using a single output measure in the specification. As already discussed, in Models 1 and 2 we used only insurers which have strictly positive outputs in the four lines of business. This reduced considerably the numbers of observations. Therefore, both for 
robustness and market representation, we extended the analysis to a higher number of insurers by summing up the four output variables into a single one. In Model 3, we use the same number of observations as in Model 2 for the sake of comparison. In this specification, there is a single aggregated output along with two output quality variables (Proportion of personal and Proportion of long tail). This procedure was often used in models for inferring technological parameters in the transportation industry (see, for instance, Dionne, Gagné and Vanasse, 1998). The two qualitative variables are statistically significant and indicate that insurers more involved in personal lines have lower costs while those more involved in long tail lines have higher costs. It is interesting to observe that the coefficients associated with the two intermediate outputs variables keep the same sign although their magnitudes change. In Model 4, the results are obtained with 5,549 observations and in model 5 with 9,129 observations. In this last model, we dropped the output quality variables because many insurers are not present in personal or long tail lines. Again the results are quite robust.

One particularity of our econometric model is related to the shadow prices of the intermediate outputs. Since these two outputs are not traded on markets but inside the firms, they are not directly observable but can be estimated. Estimated shadow prices are illustrated in Figure 1 for risk management and in Figure 2 for financial intermediation using the parameter estimates of Model 2 (with 612 insurers in the sample). ${ }^{13}$ In both cases, the average shadow price is positive indicating that, on average, insurance firms in the sample could reduce their costs further by increasing their level of risk and financial management activities. This observation is, of course, consistent with the empirical results presented in Table 2 (Model 2) where the fixed part of the coefficients associated with the two intermediate outputs are statistically significant. Figures 1 and 2 also reveal that several insurers are quite far from an optimal level of risk and financial management activities and could further reduce their costs significantly by increasing these activities. The same figures also reveal that a few firms are over-producing risk

\footnotetext{
${ }^{13}$ Even if shadow prices are computed for each observation in the sample (3,303 observations), Figures 1 and 2 report the firm-average shadow prices (612 firms). For risk management activities, the results correspond to negative value obtained from Equation 15 because increasing risk management decreases asset-liability risk.
} 
management and financial intermediation activities (negative price values) and could therefore reduce their costs by reducing the level of these activities.

Insurance-pooling efficiency results are presented in Table 4. We look at the efficiency measures computed from the estimates of the five empirical models considered in our analysis. Efficiency (1) is defined by equation (17) and is relative to the most efficient firm in the sample. Efficiency (2) is defined by equation (18) and is relative to the least efficient firm in the sample. For all models, the results are quite consistent: cost differences between 44 and $60 \%$ on average compared to the most efficient firms and cost differences between 39 and 55\% compared to the least efficient firm. Limiting our analysis to our preferred model (Model 2), we can see that, on average, firms in the sample have costs which are 49\% higher than the most efficient firm in the sample, everything else being equal. Alternatively, we also see that, on average, firms in the sample have costs which are 55\% lower than the less efficient firm in the sample used (612 observations) again, everything else being equal. These efficiency measurements must be interpreted as overall insurance-pooling activity efficiency.

\section{Conclusion}

This paper test the role of risk management and financial intermediation activities in value creation by analyzing three samples of U.S. property-liability insurers over the period 1995-2003. We argue that risk management and financial intermediation are activities that may be used by insurers to improve efficiency, where efficiency is gauged by the capacity to reduce the costs of providing insurance. We measure insurer efficiency by estimating an econometric cost frontier. Because risk management and financial intermediation are key activities for insurers, we treat these activities as endogenous. And, because the prices of risk management and financial intermediation services are not observable, we consider these two activities as intermediate outputs and estimate their shadow prices. The shadow prices are then used to isolate the contributions of risk management and financial intermediation to insurer cost efficiency, as measured by their capacity to reduce costs.

The paper also contributes to the prior literature by developing a theoretical model of value-added in the property-liability insurance industry. This is important because output estimation for financial 
services firms has been based primarily on the value-added approach in the recent literature. Our model represents a significant extension and generalization of prior models of value-added in the insurance industry. The two most important generalizations are to incorporate the role of solvency risk as a determinant of demand for insurance to explicitly add risk management as part of value added. We also generalize prior models with respect to the financial intermediation function.

The final important contribution of this paper is to introduce a new approach for the estimation of efficiency, which is particularly appropriate for financial institutions. The econometric methodology, borrowed from the exhaustible resources literature (Halvorsen and Smith, 1991; Chermak and Patrick, 2001), enables us to estimate the shadow prices of risk management and financial intermediation and thereby to show their contribution to insurer cost efficiency. The estimation of shadow prices is particularly important for financial institutions because many of the services provided by such firms are intangible and not explicitly priced. This is the case for services provided by both insurers and banks, such as risk management and financial intermediation and also for products such as demand deposits, which bundle together a variety of services, most of which are priced implicitly. Thus, our methodology is a promising approach that could be used more widely to analyze financial institutions.

The empirical results clearly indicate that risk management and financial intermediation contribute significantly to enhancing efficiency for property-liability insurers. The average shadow price for both services is positive, indicating that, on average, insurance firms in the sample could reduce their costs further by increasing their level of risk management and financial intermediation activities. The results also reveal that several insurers are quite far from an optimal level of risk management and financial intermediation activities and could further reduce their costs significantly by increasing these activities. However, a few firms are over-producing these intermediate outputs and could therefore improve their efficiency by reducing the level of these activities. 


\section{References}

Ahlgrim, K.C., D’Arcy, S.P., and Gorvett, R.W., 2004. The Effective Duration and Convexity of Liabilities for Property-Liability Insurers Under Stochastic Interest Rates. Geneva Papers on Risk and Insurance Theory 29, 75-108.

Allayannis, G. and Weston, J.P., 2001. The Use of Foreign Currency Derivatives and Firm Value. The Review of Financial Studies 14, 243-276.

Babbel, D.F. and Santomero, A.M., 1999. An Analysis of the Financial Risk Management Process Used by Life Insurers, in: J.D. Cummins and A.M. Santomero (Eds.), Changes In the Life Insurance Industry: Efficiency, Technology, and Risk Management. Springer, Boston.

Berger, A.N., 1993. "Distribution Free" Estimates of Efficiency in the U.S. Banking Industry and Tests of the Standard Distributional Assumptions. Journal of Productivity Analysis 4, 261-292.

Berger, A.N., 2000. The Integration of the Financial Services Industry: Where Are the Efficiencies? North American Actuarial Journal 4, 3, 25-45.

Berger, A.N.; Cummins, J.D., and Weiss, M.A., 1997. The Coexistence of Multiple Distribution Systems for Financial Services: The Case of Property-Liability Insurance. The Journal of Business 70, 4, 515-546.

Berger, A.N., Cummins, J.D., Weiss, M.A., and Zi, H., 2000. Conglomeration vs. Strategic Focus: Evidence From the Insurance Industry. Journal of Financial Intermediation 9, 323-362.

Berger, Allen N. and David B. Humphrey, 1992. Measurement and Efficiency Issues in Commercial Banking. In: Griliches, Zvi., ed. Output Measurement in the Service Sector, University of Chicago Press, Chicago, IL, pp. 245-279.

Brewer, E., Jackson, W.E.; Moser, J.T., 1996. Alligators in the Swamp: The Impact of Derivatives on the Financial Performance of Depository Institutions. Journal of Money, Credit, and Banking 28, 482497. 
Casu, B. and Girardone, C., 2005. An Analysis of the Relevance of Off-Balance Sheet Items in Explaining Productivity Change in European Banking. Applied Financial Economics 15, 10531061.

Casu, B., Girardone, C., and Molyneux, P., 2004. Productivity Change in European Banking: A Comparison of Parametric and Non-Parametric Approaches. Journal of Banking and Finance 28, 2521-2540.

Cebenoyan, A.S. and Strahan, P.E., 2004. Risk Management, Capital Structure and Lending at Banks. Journal of Banking and Finance 28, 19-43.

Chermak, J.M. and Patrick, R.H., 2001. A Microeconomic Test of the Theory of Exhaustible Resources. Journal of Environmental Economics and Management 42, 82-103.

Choi, B.P. and Weiss, M.A., 2005. An Empirical Investigation of Market Structure, Efficiency, and Performance in Property-Liability Insurance. Journal of Risk and Insurance 72, 635-673.

Clark, J.A. and Siems, T.F., 2002. X-Efficiency in Banking: Looking Beyond the Balance Sheet. Journal of Money, Credit, and Banking 34, 987-1013.

Crouhy, M., Galai, D., and Mark, R., 2000. Risk Management. McGraw Hill.

Cummins, J.D., Phillips, R.D., and Smith, S.D., 1997. Corporate Hedging in the Insurance Industry: The Use of Financial Derivatives by U.S. Insurers. North American Actuarial Journal 1, 13-40.

Cummins, J.D., Phillips, R.D., and Smith, S.D., 2001. Derivatives and Corporate Risk Management: Participation and Volume Decisions in the Insurance Industry. Journal of Risk and Insurance 68, 51-91.

Cummins, J.D., Phillips, R.D., and Smith, S.D., 2000. Financial Risk Management in the Insurance Industry, in: G. Dionne, (Ed.), Handbook of Insurance. Kluwer Academic Publishers, Boston, 565591.

Cummins, J.D. and Nini, G., 2002. Optimal Capital Utilization by Financial Firms: Evidence From the Property-Liability Insurance Industry. Journal of Financial Services Research 21, 15-53. 
Cummins, J.D., Rubio-Misas, M., and Zi, H., 2004. The Effect of Organizational Structure on Efficiency: Evidence from the Spanish Insurance Industry. Journal of Banking and Finance 28, 3113-3150.

Cummins, J.D. and Rubio-Misas, M., 2006. Deregulation, Consolidation, and Efficiency: Evidence from the Spanish Insurance Industry. Journal of Money, Credit, and Banking 38, 2, 323-356.

Cummins, J.D. and Weiss, M.A., 2000a. Analyzing Firm Performance in the Insurance Industry Using Frontier Efficiency Methods, in: G. Dionne, (Ed.), Handbook of Insurance. Kluwer Academic Publishers, Boston, 767-829.

Cummins, J.D. and Weiss, M.A., 2000b. The Global Market for Reinsurance: Consolidation, Capacity, and Efficiency. Brookings-Wharton Papers on Financial Services-: 2000, 159-209.

Cummins, J.D., Weiss, M.A., and Zi, H., 1999. Organizational Form and Efficiency: The Coexistence of Stock and Mutual Property-Liability Insurers. Management Science 45, 1254-1269.

Cummins, J.D. and Xie, X., 2005. Economies of Scale and Efficiency Analysis in the United States Property-Liability Insurance Industry. Working Paper, Wharton School of University of Pennsylvania, Philadelphia, Pennsylvania.

Cummins, J.D. and Zi, H., 1998. Comparison of Frontier Efficiency Methods: An Application to the U.S. Life Insurance Industry. Journal of Productivity Analysis 10, 131-152.

Davidson, R. and MacKinnon, J.G., 1993. Estimation and Inference in Econometrics. Oxford University Press, New York.

DeMarzo, P. and Duffie, D., 1991. Corporate Financial Hedging with Proprietary Information. Journal of Economic Theory 53, 2, 261-286.

Dionne, G., 2004. The Foundations of Risk Regulation for Banks: A Review of the Literature, in: The Evolving Financial System and Public Policy, Proceedings Bank of Canada Conference, 177-215.

Dionne, G., Gagné, R, and Vanasse, C., 1998. Inferring Technological Parameters from Incomplete Panel Data. Journal of Econometrics 87, 303-327.

Dionne, G. and Garand, M., 2003. Risk Management Determinants Affecting Firm’s Values in the Gold Mining Industry: New Empirical Results. Economics Letters 79, 43-52. 
Dionne, G. and Triki, T., 2004. On Risk Management Determinants: What Really Matters? Working paper 04-04, Canada Research Chair in Risk Management, HEC Montréal.

Dionne, G. and Triki, T., 2005. Risk Management and Corporate Governance: The Importance of Independence and Financial Knowledge for the Board and the Audit Committee. Working Paper 05-03, Canada Research Chair in Risk Management, HEC Montréal.

Doherty, N. and Dionne, G., 1993. Insurance with Undiversifiable Risk: Contract Structure and Organizational Form of Insurance Firms. Journal of Risk and Uncertainty 6, 2, 187-203.

Doherty, N. and Schlesinger, H., 1990. Rational Insurance Purchasing: Consideration of Contract Nonperformance. Quarterly Journal of Economics 105, 143-153.

Drzik, J., 2005. New Directions in Risk Management. Journal of Financial Econometrics 1, 26-36.

Ennsfellner, K.C., Lewis, D., and Anderson, R.I., 2004. Production Efficiency in the Austrian Insurance Industry: A Bayesian Examination. Journal of Risk and Insurance 71, 135-159.

Fenn, P., Vencappa, D., Diacon, S., Klumpes, P., and O’Brien, C., 2006. Market Structure and Efficiency of European Insurance Companies: A Stochastic Frontier Analysis. Working paper, University of Nottingham, Nottingham, England.

Fried, H.O., Schmidt, S.S., and Lovell, C.A.K., 1993. The Measurement of Productive Efficiency. Oxford University Press, New York.

Froot, K., Scharfstein, D., and Stein, J., 1993. Risk Management: Coordinating Corporate Investment and Financing Policies. The Journal of Finance 48, 5, 1629-1658.

Girardone, C., Molyneux, P., and Gardener, E.P.M., 2004. Analysing the Determinants of Bank Efficiency: The Case of Italian Banks. Applied Economics 36, 215-227.

Graham, J. and Rogers, D., 2002. Do Firms Hedge in Response to Tax Incentives? The Journal of Finance 57, 2, 815-839.

Graham, J. and Smith, C. Jr., 1999. Tax Incentives to Hedge. The Journal of Finance 54, 6, 2241-2262. 
Greene, W.H., 1993. The Econometric Approach to Efficiency Analysis, in: H.O. Fried, C.A.K. Lovell, and S.S. Schmidt (Eds.), The Measurement of Productive Efficiency. Oxford University Press, New York.

Greene, W.H., 2000. Econometric Analysis. NJ: Prentice-Hall Inc., Upper Saddle River.

Greene, W.H. and Segal, D., 2004. Profitability and Efficiency in the U.S. Life Insurance Industry. Journal of Productivity Analysis 21, 229-247.

Halvorsen, R. and Smith, T.R., 1991. A Test of the Theory of Exhaustible Resources. The Quarterly Journal of Economics 106, 1, 123-140.

Hughes, J.P., Mester, L.J., and Moon, C.-G., 2001. Are Scale Economies in Banking Elusive or Illusive? Evidence Obtained by Incorporating Capital Structure and Risk-Taking Into Models of Bank Production. Journal of Banking and Finance 25, 2160-2208.

Hussels, S. and Ward, D., 2006. The Impact of Deregulation on the German and U.K. Life Insurance Markets: An Analysis of Efficiency and Productivity Over 1991-2002. Working paper, University of Bradford, Bradford, England.

Klumpes, P.J.M., 2004. Performance Benchmarking in Financial Services: Evidence from the U.K. Life Insurance Industry. Journal of Business 77, 257-273.

Mahlberg, B. and Url, Thomas, 2003. Effects of the Single Market on the Austrian Insurance Industry. Empirical Economics 28, 813-838.

Merton, R. and Perold, A., 1993. Theory of Risk Capital in Financial Firms. Journal of Applied Corporate Finance 6, 16-32.

Mester, L.J., 1996. A Study of Bank Efficiency Taking Into Account Risk Preferences. Journal of Banking and Finance 20, 1025-1045.

Morisson, A.D. and White, L., 2005. Crises and Capital Requirements in Banking. The American Economic Review 95, 5, 1548-1572.

Nelson, J.M., Moffitt, J.S., and Affleck-Graves, J., 2005. The Impact of Hedging on the Market Value of Equity. Journal of Corporate Finance 11, 851-881. 
Pagan, A., 1984. Econometric Issues in the Analysis of Regressions with Generated Regressors. International Economic Review 25, 221-247.

Pastor, J.M. and Serrano, L., 2005. Efficiency, Endogenous and Exogenous Credit Risk in the Banking Systems of the Euro Area. Applied Financial Economics 15, 631-649.

Regan, L. and Tennyson, S., 2000. Insurance Distribution Systems, in: G. Dionne (Ed.), Handbook of Insurance. Kluwer Academic, Boston, 709-748.

Santomero, A.M. and Babbel, D.F., 1997. Financial Risk Management by Insurers: An Analysis of the Process. Journal of Risk and Insurance 64, 231-270.

Schrand, C. and Unal, H., 1998. Hedging and Coordinated Risk Management: Evidence from Thrift Conversions. Journal of Finance 53, 979-1013.

Smith, C. and Stulz, R., 1985. The Determinants of Firms’ Hedging Policies. Journal of Financial and Quantitative Analysis 20, 4, 391-405.

Staking, K.B. and Babbel, D.F., 1995. The Relation Between Capital Structure, Interest Rate Sensitivity, and Market Value in the Property-Liability Insurance Industry. Journal of Risk and Insurance 62, 690-718.

Stiroh, K.J., 2000. How Did Bank Holding Companies Prosper in the 1990s? Journal of Banking and Finance 24, 1703-1745.

Stulz, R., 1990. Managerial Discretion and Optimal Financing Policies. Journal of Financial Economics 26, 1, 3-28.

Taylor, Greg, 2000. Loss Reserving: An Actuarial Perspective. Kluwer Academic Publishers, Boston.

Triki, T., 2005. Research on Corporate Hedging Theories: A Critical Review of the Evidence to Date. Working paper 05-04, Canada Research Chair in Risk Management, HEC Montréal.

Tufano, P., 1996. Who Manages Risk? An Empirical Examination of Risk Management Practices in the Gold Mining Industry. The Journal of Finance 51, 4, 1097-1137. 
TABLE 1

Summary Statistics for Variables Used in Cost Function Estimation: 1995-2003

\begin{tabular}{|c|c|c|c|c|}
\hline \multirow[b]{2}{*}{ Variable } & \multicolumn{2}{|c|}{$\begin{array}{c}\text { Sample } 1 \\
(3,303 \text { observations) } \\
\end{array}$} & \multicolumn{2}{|c|}{$\begin{array}{c}\text { Sample } 2 \\
(9,129 \text { observations) }\end{array}$} \\
\hline & Mean & $\begin{array}{l}\text { Standard } \\
\text { Deviation }\end{array}$ & Mean & $\begin{array}{l}\text { Standard } \\
\text { Deviation }\end{array}$ \\
\hline \multicolumn{5}{|l|}{ Intermediate Outputs } \\
\hline Invested assets & $1,583.92$ & $5,697.63$ & 644.63 & $3,516.55$ \\
\hline Asset-liability risk & $14,775.70$ & $57,897.15$ & $5,960.91$ & $35,606.04$ \\
\hline \multicolumn{5}{|c|}{ Output Quantities and Output Prices } \\
\hline Long-tail personal & 191.52 & $1,027.95$ & 70.54 & 625.06 \\
\hline Short-tail personal & 86.66 & 471.24 & 32.63 & 286.90 \\
\hline Long-tail commercial & 165.53 & 533.87 & 68.39 & 331.02 \\
\hline Short-tail commercial & 42.94 & 139.57 & 21.01 & 110.71 \\
\hline Total output & 486.65 & 1851.91 & 192.57 & $1,139.48$ \\
\hline Proportion of personal & 0.5489 & 0.3214 & 0.3758 & 0.3904 \\
\hline Proportion of long-tail & 0.7163 & 0.1723 & 0.6909 & 0.3277 \\
\hline Price of long-tail personal & 0.4482 & 1.0919 & 0.2895 & 1.0171 \\
\hline Price of short-tail personal & 0.5587 & 1.3003 & 0.4071 & 2.0543 \\
\hline Price of long-tail commercial & 1.3674 & 7.5824 & 1.2734 & 8.5475 \\
\hline Price of short-tail commercial & 0.9516 & 2.8124 & 4.0145 & 162.6139 \\
\hline Price of total output & 0.4940 & 0.4168 & 3.5011 & 162.3953 \\
\hline \multicolumn{5}{|l|}{ Inputs Prices } \\
\hline Administrative labour & 948.60 & 172.48 & 943.96 & 164.69 \\
\hline Agent labour & 802.11 & 152.1 & 811.04 & 157.92 \\
\hline Risk labour & $2,073.07$ & $1,129.41$ & $2,035.99$ & $1,065.63$ \\
\hline Material/Business labour & 614.04 & 197.34 & 603.75 & 183.46 \\
\hline Debt Price & 0.0576 & 0.0181 & 0.0586 & 0.0185 \\
\hline Equity Price & 0.1684 & 0.064 & 0.1777 & 0.0722 \\
\hline \multicolumn{5}{|l|}{ Others } \\
\hline Equity & 890.93 & $3,643.78$ & 362.81 & $2,241.21$ \\
\hline Debt & $1,210.84$ & $3,964.75$ & 487.61 & $2,458.77$ \\
\hline Assets & $1,902.72$ & $6,920.67$ & 777.06 & $4,325.34$ \\
\hline Total costs & 432.47 & $1,503.19$ & 172.91 & 927.15 \\
\hline Number of observations & \multicolumn{2}{|c|}{3,303} & \multicolumn{2}{|c|}{9,129} \\
\hline Number of insurers & \multicolumn{2}{|c|}{612} & \multicolumn{2}{|c|}{1,634} \\
\hline
\end{tabular}

Note: Quantities of intermediate outputs, quantities of outputs and assets are in millions of real 1995 dollars. Equity, Debt and Total costs are in million of current dollars. 


\section{TABLE 2}

Models specified with four outputs.

Model 1: only the intercept is random.

Model 2: random intercept and random coefficients for Invested assets and Asset-liability risk.

\begin{tabular}{|l|c|c|c|c|}
\hline & \multicolumn{2}{|c|}{ Model 1 } & \multicolumn{2}{c|}{ Model 2 } \\
\hline & Estimate & t ratio & Estimate & t ratio \\
\hline Intercept & 12.9777 & 293.16 & 12.9032 & 232.61 \\
\hline Invested assets & -0.4043 & -3.01 & -0.5428 & -3.50 \\
\hline Asset-liability risk & 0.4066 & 3.32 & 0.5539 & 3.83 \\
\hline Long-tail personal & 0.2322 & 14.72 & 0.2065 & 13.56 \\
\hline Short-tail personal & 0.1541 & 9.74 & 0.1391 & 9.22 \\
\hline Long-tail commercial & 0.2700 & 21.53 & 0.2637 & 21.79 \\
\hline Short-tail commercial & 0.1569 & 10.76 & 0.1246 & 8.63 \\
\hline Agent labour & 0.4172 & 2.71 & 0.5502 & 3.46 \\
\hline Risk labour & -0.0383 & -0.77 & -0.0227 & -0.45 \\
\hline Business labour & -0.0031 & -0.03 & -0.0376 & -0.39 \\
\hline Debt price & 0.0930 & 1.04 & 0.1269 & 1.50 \\
\hline Equity price & 0.2689 & 5.86 & 0.2195 & 5.22 \\
\hline Year96 & -0.0855 & -5.44 & -0.0734 & -5.52 \\
\hline Year97 & 0.0209 & 1.24 & 0.0080 & 0.54 \\
\hline Year98 & -0.0092 & -0.38 & -0.0278 & -1.26 \\
\hline Year99 & 0.0476 & 1.78 & 0.0128 & 0.51 \\
\hline Year00 & 0.0229 & 0.84 & 0.0172 & 0.68 \\
\hline Year01 & -0.0505 & -0.88 & -0.0236 & -0.42 \\
\hline Year02 & 0.0247 & 0.29 & -0.0080 & -0.10 \\
\hline Year03 & 0.0566 & 0.52 & 0.0025 & 0.02 \\
\hline Number of observations & 3,303 & & 3,303 & \\
\hline Number of insurers & 612 & & 612 & \\
\hline -2 Log Likelihood & $1,113.2$ & & 592.9 & \\
\hline
\end{tabular}

Note: Second-order terms are not presented but are available upon request. We present here estimated $t$ ratios. In the case of Model 2, simulated $t$ ratios give the same results regarding the statistical significance of the estimated coefficients. These simulation results are also available upon request. 
TABLE 1'

Other Control Variables

\begin{tabular}{|c|c|c|c|c|}
\hline \multirow[b]{2}{*}{ Variable } & \multicolumn{2}{|c|}{$\begin{array}{c}\text { Sample } 1 \\
\text { (3,303 observations) }\end{array}$} & \multicolumn{2}{|c|}{$\begin{array}{c}\text { Sample } 2 \\
(9,129 \text { observations })\end{array}$} \\
\hline & Mean & $\begin{array}{l}\text { Standard } \\
\text { Deviation }\end{array}$ & Mean & $\begin{array}{l}\text { Standard } \\
\text { Deviation }\end{array}$ \\
\hline \multicolumn{5}{|l|}{ Dummy variables } \\
\hline Group dummy (= 1 if group member) & 0.6691 & 0.4706 & 0.4116 & 0.4922 \\
\hline Stock ownership dummy (= 1 if stock insurer) & 0.5235 & 0.4996 & 0.5395 & 0.4985 \\
\hline Class 1 ( $=1$ if insurer rating is $A++$ or $A+$ ) & 0.2095 & 0.407 & 0.0957 & 0.2942 \\
\hline Class 2 (= 1 if insurer rating is $A$ ) & 0.2452 & 0.4303 & 0.1784 & 0.3829 \\
\hline Class 3 (= 1 if insurer rating is $A-)$ & 0.2322 & 0.4223 & 0.2047 & 0.4035 \\
\hline Class 4 (= 1 if insurer rating is $B^{++}$or $B^{+}$) & 0.1674 & 0.3734 & 0.1799 & 0.3841 \\
\hline Class 5 (= 1 if insurer rating is $B$ ) & 0.0424 & 0.2015 & 0.0381 & 0.1915 \\
\hline Class 6 ( $=1$ if insurer rating is $B-$ ) & 0.0233 & 0.1509 & 0.0205 & 0.1420 \\
\hline
\end{tabular}


TABLE 3

Models specified with aggregated outputs

Model 3: random intercept and coefficients for 3303 observations

Model 4: random intercept and coefficients for 5549 observations

Model 5: random intercept and coefficients for 9129 observations

\begin{tabular}{|c|c|c|c|c|c|c|}
\hline & \multicolumn{2}{|c|}{ Model 3} & \multicolumn{2}{|c|}{ Model 4} & \multicolumn{2}{|c|}{ Model 5} \\
\hline & Estimate & t ratio & Estimate & t ratio & Estimate & t ratio \\
\hline Intercept & 12.8947 & 289.22 & 12.3759 & 303.49 & 11.8097 & 266.00 \\
\hline Invested assets & -1.1799 & -8.14 & -0.5352 & -4.45 & -1.3444 & -9.57 \\
\hline Asset-liability risk & 1.1401 & 8.45 & 0.5971 & 5.35 & 1.3502 & 10.66 \\
\hline Total output & 0.8736 & 60.19 & 0.8870 & 74.89 & 0.7963 & 74.43 \\
\hline Proportion of personal & -0.1026 & -5.87 & -0.0705 & -5.27 & & \\
\hline Proportion of long tail & 0.1422 & 2.97 & 0.1010 & 3.28 & & \\
\hline Agent labour & 0.5716 & 3.96 & 0.5408 & 3.96 & 0.3606 & 2.93 \\
\hline Risk labour & -0.0454 & -1.00 & -0.0543 & -1.25 & -0.0285 & -0.72 \\
\hline Business labour & -0.0308 & -0.35 & 0.0388 & 0.46 & -0.1557 & -2.02 \\
\hline Debt price & 0.3208 & 4.20 & 0.1147 & 1.72 & 0.2288 & 4.57 \\
\hline Equity price & 0.1999 & 5.24 & 0.2292 & 6.30 & 0.3268 & 10.45 \\
\hline Year96 & -0.0389 & -3.32 & -0.0277 & -2.42 & -0.0076 & -0.81 \\
\hline Year97 & -0.0119 & -0.88 & 0.0359 & 2.87 & 0.0169 & 1.55 \\
\hline Year98 & -0.0457 & -2.28 & -0.0092 & -0.51 & -0.0179 & -1.13 \\
\hline Year99 & -0.0425 & -1.86 & 0.0168 & 0.89 & 0.0202 & 1.38 \\
\hline Year00 & 0.0269 & 1.21 & 0.0050 & 0.25 & 0.0620 & 3.67 \\
\hline Year01 & 0.0973 & 1.95 & -0.0520 & -1.21 & 0.0944 & 3.00 \\
\hline Year02 & 0.1663 & 2.26 & -0.0188 & -0.30 & 0.1450 & 3.10 \\
\hline Year03 & 0.1616 & 1.75 & 0.0799 & 0.96 & 0.2582 & 4.00 \\
\hline Number of observations & \multicolumn{2}{|c|}{ 3,303 } & \multicolumn{2}{|c|}{5,549} & \multicolumn{2}{|c|}{9,129} \\
\hline Number of insurers & \multicolumn{2}{|c|}{612} & \multicolumn{2}{|c|}{1,013} & \multicolumn{2}{|c|}{1,643} \\
\hline -2 Log Likelihood & \multicolumn{2}{|c|}{-262.8} & \multicolumn{2}{|c|}{$1,767.1$} & \multicolumn{2}{|c|}{$5,097.1$} \\
\hline
\end{tabular}

Note: Second-order terms are not presented but are available upon request. 
TABLE 4

Insurance-pooling Efficiency Results

\begin{tabular}{|c|c|c|c|c|c|}
\hline Variable & $\mathbf{N}$ & Mean & $\begin{array}{l}\text { Standard } \\
\text { Deviation }\end{array}$ & Minimum & Maximum \\
\hline \multicolumn{6}{|l|}{ Model 1} \\
\hline Efficiency(1) & 612 & 0.559867 & 0.205727 & 0.249078 & 1 \\
\hline Efficiency(2) & 612 & 0.486696 & 0.203126 & 0 & 0.750922 \\
\hline \multicolumn{6}{|l|}{ Model 2} \\
\hline Efficiency(1) & 612 & 0.490595 & 0.223183 & 0.178848 & 1 \\
\hline Efficiency(2) & 612 & 0.546886 & 0.223238 & 0 & 0.821152 \\
\hline \multicolumn{6}{|l|}{ Model 3} \\
\hline Efficiency(1) & 612 & 0.600591 & 0.169435 & 0.334478 & 1 \\
\hline Efficiency(2) & 612 & 0.397756 & 0.171169 & 0 & 0.665523 \\
\hline \multicolumn{6}{|l|}{ Model 4} \\
\hline Efficiency(1) & 1,013 & 0.580427 & 0.167901 & 0.327887 & 1 \\
\hline Efficiency(2) & 1,013 & 0.389026 & 0.170473 & 0 & 0.672113 \\
\hline \multicolumn{6}{|l|}{ Model 5} \\
\hline Efficiency(1) & 1,643 & 0.448392 & 0.218786 & 0.16348 & 1 \\
\hline Efficiency(2) & 1,643 & 0.541521 & 0.224196 & 0 & 0.83652 \\
\hline
\end{tabular}

Notes:

Efficiency(1) is obtained from equation (17).

Efficiency(2) is obtained from equation (18).

The results are obtained from truncated measures, as in Berger (1993). We set the top and bottom 5\% to the $5^{\text {th }}$ and $95^{\text {th }}$ percentiles, respectively, of their distribution. 


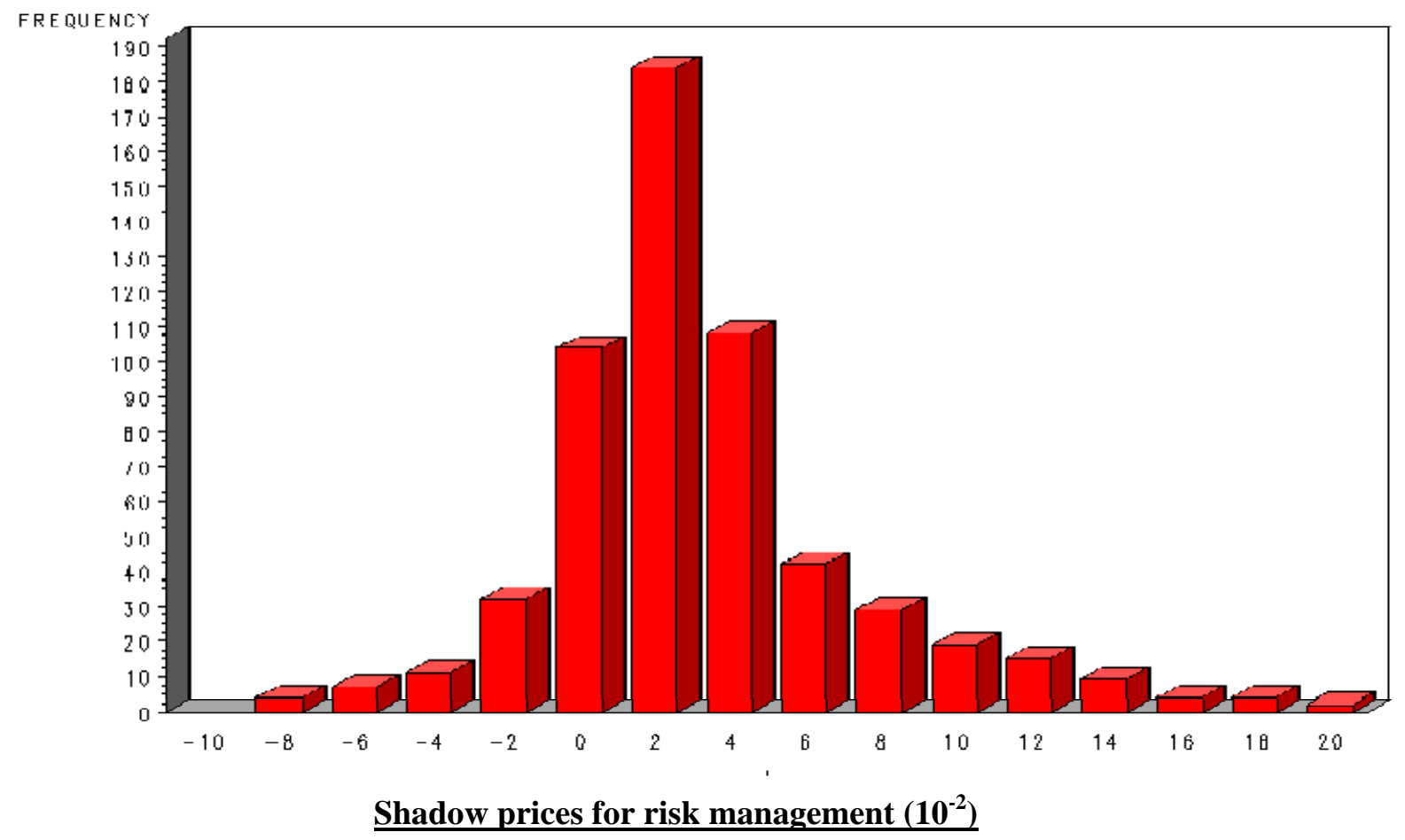

Figure 1. The shadow prices for risk management. These prices are obtained from equation (15) applied to Model 2. The mean of the shadow prices for risk management is 0.0552 . 


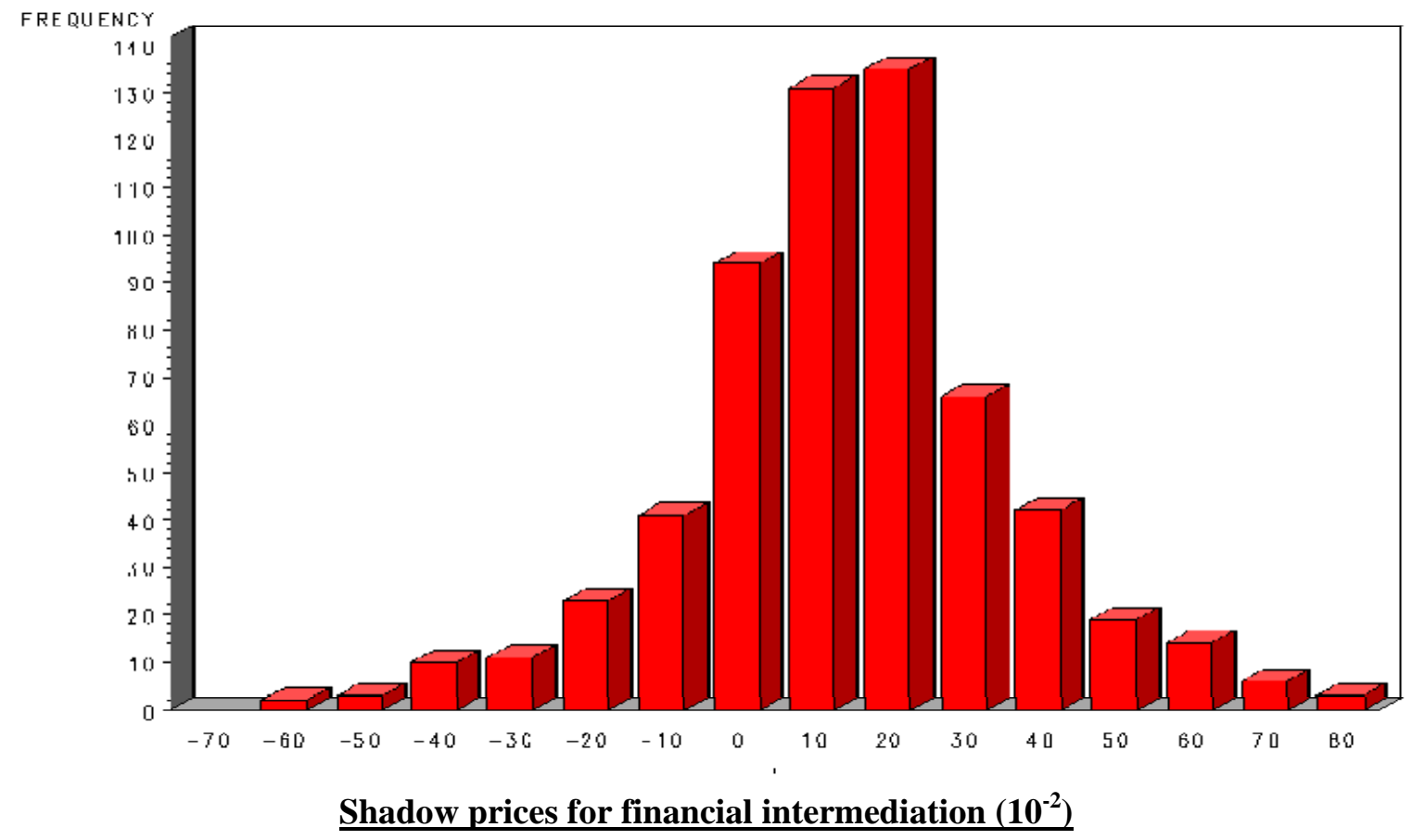

Figure 2. The shadow prices for financial intermediation. These prices are obtained from equation (16) applied to Model 2. The mean of the shadow prices for financial intermediation is 0.0967 . 


\section{Appendix}

In a first step, we assume that there is a solvency risk but the insurer does not use any risk management activity. We propose the following notation:

$p \quad$ is the probability of the solvency risk;

$r_{e}$ is the required return by equity holders;

$r \quad$ is the required return by policyholders;

$r_{a}$ is the investment return;

$e_{q}$ is the insurer expenses for risk pooling and financial management as proportion of expected insurance coverage Q; it is paid even when the insurer is insolvent.

So, the premium can be written as:

$$
P=\frac{(1-p)\left(Q+r_{e} E\right)+e_{q} Q}{(1+r)}
$$

The corresponding value added is:

$$
V=\frac{\left(1+r_{a}\right)}{(1+r)}\left((1-p)\left(Q+r_{e} E\right)+e_{q} Q\right)+r_{a} E-(1-p) Q-(1-p) r_{e} E
$$

or equivalently to:

$$
V=m\left[(1-p)\left(Q+r_{e} E\right)+e_{q} Q\right]+e_{q} Q+r_{a} E,
$$

where $1+m=\frac{1+r_{a}}{1+r} ; m>0$ when $r_{a}>r$.

We now assume that the insurer uses risk management to reduce the solvency risk. We define:

$h$ as the hedging ratio;

$p(1-h)$ as the new default probability of solvency risk;

$e_{h}$ measures expenses for hedging; it is proportional to hedging ratio and expected insurance coverage;

$e_{q h}=e_{q}+h e_{h}$ 
$r_{e}$ is the required return by equity holders. $r_{e}$ is the same as before because equity holders diversify their solvency risk in financial markets. In other words, they can diversify the specific risk by themselves; $r_{h}$ is the new required return by policyholders. When $h>0$ then $r_{h}<r$.

When the default risk decreases, policyholders reduce their required return because they are less exposed to the solvency risk.

$$
1+r_{h}=\frac{1+r}{1+m_{p}}
$$

Since $r_{h} \leq r$ then $m_{p} \geq 0$ (when $h=0$ we get $m_{p}=0$ ).

The insurance premium becomes:

$$
\begin{gathered}
P_{P F M}=\frac{(1-p+p h)\left(Q+r_{e} E\right)+e_{q h} Q}{\left(1+r_{h}\right)} \\
P_{P F M}=\left(1+m_{p}\right) \frac{(1-p)\left(Q+r_{e} E\right)+e_{q} Q}{(1+r)}+\frac{Q h e_{h}+p h\left(Q+r_{e} E\right)}{\left(1+r_{h}\right)} \\
P_{P F M}=P+m_{p} P+\frac{h e_{h} Q+p h\left(Q+r_{e} E\right)}{\left(1+r_{h}\right)}
\end{gathered}
$$

As a result policyholders are ready to pay an extra premium to reduce the solvency risk. The value added becomes:

$$
V_{P F M}=\frac{\left(1+r_{a}\right)}{\left(1+r_{h}\right)}\left[(1-p+p h)\left(Q+r_{e} E\right)+e_{q h} Q\right]+r_{a} E-(1-p+p h)\left(Q+r_{e} E\right)
$$

We can write:

$$
\frac{1+r_{a}}{1+r_{h}}=\left(1+m_{r}\right)=\frac{1+r_{a}}{1+r} \times \frac{1+r}{1+r_{h}}=(1+m)\left(1+m_{p}\right)
$$

Setting:

$$
W=Q(1+e)+r_{e} E
$$

we obtain: 


$$
\begin{gathered}
V_{P F M}=m_{r}\left[(1-p+p h) W+e_{q h} Q\right]+e_{q h} Q+r_{a} E \\
V_{P F M}=m_{r}\left[(1-p) W+e_{q} Q\right]+m_{r}\left[p h W+h e_{h} Q\right]+e_{h q} Q+r_{a} E \\
V_{P F M}=m\left[(1-p) W+e_{q} Q\right]+e_{q} Q+r_{a} E+m_{p}(1+m)\left[(1-p) W+e_{q} Q\right]+m_{r}\left[p h W+h e_{h} Q\right]+h e_{h} Q \\
V_{P F M}=V+m_{p}(1+m)\left[(1-p) W+e_{q} Q\right]+m_{r}\left[p h W+h e_{h} Q\right]+h e_{h} Q
\end{gathered}
$$

So the net value added of risk management is equal to:

$$
V_{P F M}-V=m_{p}(1+m)\left[(1-p) W+e_{h} Q\right]+m_{r}\left[p h W+h e_{h} Q\right]+h e_{h} Q>0
$$

when $m_{r}>0$ since $m_{p}>0$ when $h>0$. 


\section{Liste des cahiers de recherche publiés par les professeurs 2005-2006}

\section{Institut d'économie appliquée}

IEA-05-01 DÉSIRÉ VENCATACHALLUM ET BRUNO VERSAEVEL. « R\&D Delegation in a Duopoly with Spillovers », 57 pages.

IEA-05-02 MiCHEL NORMANDIN ET PASCAL ST-AMOUR.. « An Empirical Analysis of U.S. Aggregate Portfolio Allocations », 33 pages.

IEA-05-03 MARTIN BOILEAu ET MiCHEL nORMANDin. « Closing International Real Business Cycle Models with Restricted Financial Markets », 36 pages.

IEA-05-04 GEORGES DIONNE ET BENOIT DOSTIE. «New Evidence on the Determinants of Absenteeism Using Linked Employer-Employee Data », 35 pages.

IEA-05-05 MAURICE N. MARCHON. «Perspectives économiques canadiennes dans un contexte international », 27 pages.

IEA-05-06 RAYNAULD, JACQUES. «L'efficacité de l'apprentissage en ligne: le cas d'un cours d’économie à HEC Montréal », 10 pages

IEA-05-07 MICHEL NORMANDIN ET BRUNO POWO FOSSO. «Global versus Country-Specific Shocks and International Business Cycles», 44 pages.

IEA-05-08 RAYNAULD, JACQUES. « Le programme Virtuose : les ordinateurs portatifs et l'intégration des TIC à HEC Montréal - 1996-2001 », 88 pages 
IEA-06-01 DOSTIE, BENOIT ET LÉGER PIERRE THOMAS. « Self-selection in migration and returns to unobservable skills », 88 pages

IEA-06-02 JÉRÉMY LAURENT-LUCCHETTI AND ANDREW LEACH. «Induced innovation in a decentralized model of climate change », 34 pages.

IEA-06-03 BENOIT DOSTIE, RAJSHRI JAYARAMAN AND MATHIEU TRÉPANIER. « The Returns to Computer Use Revisited, Again », 27 pages.

IEA-06-04 MiCHEL NORMANDIN. « The Effects of Monetary-Policy Shocks on Real Wages: A MultiCountry Investigation », 38 pages.

IEA-06-05 MiChel NORMAndin. « Fiscal Policies, External Deficits, and Budget Deficits », 50 pages. 